Negative-pressure wound therapy (NPWT) is used to treat many different types of wounds, but there is still a lack of large studies describing its effectiveness in breast surgery. Enhanced recovery, reduction of complications, and good scar quality might be improved by the application of NPWT. Existing data show that vacuumassisted closure (VAC) application after expander-based breast reconstruction may be beneficial because of decreasing overall complications in comparison with standard wound treatment. There are few cases in which the use of negative pressure resulted in healing of complicated breast wounds after implant insertion - most breasts achieved healing, wherein duration of NPWT ranged from seven to 21 days. The use of NPWT leads to a decrease of seroma formation (from $70 \%$ to $15 \%$ ), the mean percutaneous aspirated volume (from $193 \mathrm{ml}$ to $26 \mathrm{ml}$ ) and the numbers of percutaneous aspirations (from three to one) in latissimus dorsi flap reconstruction. Furthermore, a prospective, within-patient, randomised study with 200 participants showed that treating closed incisional wounds after reduction mammoplasty with a VAC system resulted in a decrease of overall complications and protected against wound dehiscence. In the literature, there are cases showing that NPWT may be useful for the successful treatment of chronic and non-healing wounds, included non-puerperal mastitis and surgical sites affected by radiation therapy due to breast cancer. There is still a need for evidence confirming the effectiveness of NPWT in breast surgery because of the deficiency of large prospective studies that compare NPWT with standard treatment.

Key words: breast, breast reconstruction, negative-pressure wound therapy, wounds.

Contemp Oncol (Pozn) 2019; 23 (2): 69-73 DOI: https://doi.org/10.5114/wo.2019.85199

\section{Is negative-pressure wound therapy beneficial in modern-day breast surgery?}

\author{
Damian Matusiak, Mateusz Wichtowski, Karolina Pieszko, \\ Dominik Kobylarek, Dawid Murawa
}

Chair of Surgery and Oncology, Clinic of General Surgery and Surgical Oncology, Faculty of Medicine and Health Sciences, University of Zielona Gora, Poland

\section{Introduction}

Over the last three decades, negative-pressure wound therapy (NPWT) has been widely used to treat many different types of wounds, especially non-healing and chronic wounds [1, 2]. Generating negative pressure leads to excess fluid removal, reduction of oedema, increased dermal perfusion, stimulation of granulation tissue formation, and reduced bacterial colonisation [1-3]. It has been proven that application of vacuum-assisted closure (VAC) normalises the stress distributions around the closed incision in skin by up to $50 \%$, which is connected with a reduction of the probability of dehiscence, poor cosmesis, and scarring $[4,5]$. The NPWT device consists of a foam dressing, adhesive drape, and a trackpad that is applied on top of the drape and connected via a tube to the therapy unit, which generates sub-atmospheric pressure [3]. Despite the many gains described below, the use of this technique in breast surgery is not as frequent as in other surgical branches [6, 7].

Nowadays there are an increased number of tissue-expander techniques. The most common complications accompanying implant-based breast surgery are skin flap necrosis (10.9\%), seroma (6.9\%), infection (5.7\%), cellulitis (2\%), and haematoma (1.3\%) [8]. Enhanced recovery, reduction of complications, and good scar quality can be improved by the application of NPWT $[2,6,9-13]$. Furthermore, the aesthetic results of breast surgery should be taken into consideration because of its psychological effect [10, 13-15]. Although the daily costs of VAC application are higher, the shorter duration of therapy with improved patient comfort seem to be a beneficial solution [16]. In this review, data are presented according to the usefulness and effectiveness of VAC systems in breast surgery.

\section{Analysis}

In this article we used the PubMed, Science Direct, and Wiley Online Library databases to search the literature; 40 publications were found by searching the phrases "NPWT breast surgery" and "VAC breast surgery". Original papers and case reports have been included; papers repeated in different databases and articles that do not refer to the use of NPWT in breast surgery were excluded. After selection, 13 original papers and case reports were finally included in this literature review.

\section{The use of NPWT in breast reconstruction with the use of implants}

At the present, implant-based reconstruction after mastectomy is more common because of the shorter operation time and reduced donor-site morbidity [15]. Prevention of surgical site complications in oncological patients is crucial to avoid delay of chemotherapy and radiation treatments $[15,16]$. 
Kim et al. demonstrated that the use of incisional NPWT after expander-based breast reconstruction may be beneficial because it decreases the overall number of complications in comparison with standard wound treatment (11.1\% vs. $27.9 \%, p=0.019)$, and skin necrosis is statistically significantly less frequent in patients treated with NPWT (8.9\% vs. $23.5 \%$ in standard wound care, $p=0.038)$, which means that many patients have the chance to avoid reoperation [15]. Based on Gabriel et al. (2016), there is strong probability that regardless of mastectomy type (nipple sparing, skin sparing, and reduction pattern mastectomy) most postoperative wounds will probably achieve healing three months after surgical treatment in connection with incisional NPWT [17].

In 2015 Holt et al. conducted a study in which 24 patients were subjected to either therapeutic mammoplasty or skin-sparing mastectomy, immediate reconstruction on the side affected by breast cancer, and contralateral reduction. Surgical incision on the therapeutic side is treated with negative pressure $(-80 \mathrm{mmHg}$, removed at the first appointment on day 6 in all cases), and reduction side was dressed with conventional dressings. The overall rate of wound breakdown in the 24 patients was $4.2 \%$ on the therapeutic side compared with $16.7 \%$ on the reduction side, and the mean time to healing was 10.7 days in the therapeutic side treated with the NPWT compared with 16.1 days on the reduction side, although due to the small sample size these results did not allow meaningful testing for statistical significance [18].

Gabriel et al. in 2018 performed a retrospective review of records for adult female patients who underwent breast reconstruction postmastectomy. All patients underwent nipple-sparing, skin-sparing, or skin-reducing mastectomy with immediate or delayed expander-implant reconstruction (prepectoral tissue expander placement or partial submuscular/partial acellular dermal matrix expander placement). Analysis of 356 female patients (NPWT group = 177 , standard care group $=179$ ), accounting for 665 reconstructed breasts (NPWT $=331$, standard care $=334$ ), were analysed; patients who received radiation during treatment were excluded. Patients in the NPWT group were older and had higher incidences of diabetes, hypertension, and chemotherapy treatment. Negative-pressure therapy was applied at $-125 \mathrm{mmHg}$; all patients were discharged home after one night and instructed to return for follow-up on postoperative days 3 and 7. In comparison with standard wound care, using the VAC system resulted in a decrease in overall complications ( $15.9 \%$ vs. $8.5 \%, p=0.0092)$, surgical-site infections ( $4.5 \%$ vs. $2.1 \%, p=0.0225)$, wound dehiscence $(5.4 \%$ vs. $2.4 \%, p=0.0178)$, necrosis $(9.3 \%$ vs. $5.1 \%$, $p=0.007$ ), seroma formation ( $5.7 \%$ vs. $1.8 \%, p=0.0106$ ), and returns to the operating room (5.4\% vs. $2.4 \%, p=$ 0.0496). Two drains were received by $329 / 331$ breasts (99.4\%) in the NPWT group and by $180 / 334$ (53.9\%) breasts in the standard care group; however, the mean number of days from drain placement to removal of the final drain per breast was 9.9 days in the NPWT group and 13.1 days for the standard care group ( $p<0.0001$ ) [19]. In Table 1 data summarised from studies related to the effectiveness of VAC systems used in implant-based breast surgery.

\section{Treatment of infected wounds after breast surgery using NPWT}

In the literature there are few cases describing the use of NPWT to heal complicated breast wounds after implant

Table 1. The use of NPWT in implant-based breast reconstruction surgery - summary

\begin{tabular}{|c|c|c|c|c|c|c|}
\hline Study & $\begin{array}{l}N \text {, range of } \\
\text { age (years) }\end{array}$ & $\begin{array}{l}\text { No. of patients } \\
\text { with NPWT, } \\
\text { no. of breasts }\end{array}$ & $\begin{array}{l}\text { No. of patients } \\
\text { with standard } \\
\text { treatment, } \\
\text { no. of breasts }\end{array}$ & $\begin{array}{l}\text { Comparison } \\
\text { of overall } \\
\text { complications }\end{array}$ & $\begin{array}{l}\text { NPWT } \\
\text { duration } \\
\text { time } \\
\text { (days) }\end{array}$ & Outcome of NPWT \\
\hline $\begin{array}{l}\text { Gabriel et al. } 2016 \text {, } \\
\text { retrospective cohort } \\
\text { study }\end{array}$ & $13,27-62$ & 13,26 & 0,0 & $\begin{array}{l}5 / 26 \text { breasts } \\
(19 \%)^{\text {b }} \text { vs. no } \\
\text { data }\end{array}$ & 4.3 & $\begin{array}{c}\text { By 3-month follow-up } \\
24 \text { of } 25(96 \%) \text { breasts } \\
\text { achieved healing }\end{array}$ \\
\hline $\begin{array}{l}\text { Dae Young Kim et al. } \\
\text { 2016, prospective } \\
\text { cohort study }\end{array}$ & $\begin{array}{c}206 \\
34.8-49.6\end{array}$ & 44,45 & 162,183 & $\begin{array}{l}\text { 5/45 breasts } \\
(11.1 \%)^{d} \text { vs. } \\
51 / 183 \text { breasts } \\
(27.9 \%)^{\mathrm{e}}\end{array}$ & 3 & - \\
\hline $\begin{array}{l}\text { Holt et al. } 2015 \text {, } \\
\text { case series }\end{array}$ & $24,42-70$ & 24,24 & 24,24 & $\begin{array}{c}1 / 24 \text { breasts } \\
(4.2 \%)^{f} \text { vs. } 4 / 24 \\
\text { breasts }(16.7 \%)^{g}\end{array}$ & 6 & $\begin{array}{l}\text { At days } 6 \text { and } 12 \text { nursing } \\
\text { staff found an improvement } \\
\text { in wound appearance on } \\
\text { the treated side compared } \\
\text { with the contralateral side } \\
\text { in the majority of patients }\end{array}$ \\
\hline $\begin{array}{l}\text { Gabriel et al. } 2018 \text {, } \\
\text { retrospective cohort } \\
\text { study }\end{array}$ & $356,40-64.2$ & 177,331 & 179,334 & $\begin{array}{c}28 \text { breasts } \\
(8.5 \%)^{\mathrm{h}} \text { vs. } 53 \\
\text { breasts }(15.9 \%)^{\mathrm{h}}\end{array}$ & 7 & - \\
\hline
\end{tabular}

aperation types: nipple-sparing, skin-sparing, and reduction pattern mastectomy. ${ }^{b}$ Superficial dehiscence (3/5), skin flap necrosis (1/5) and delayed haematoma (1/5). 'Only flap necrosis in the breast of an obese, diabetic (with HGBA1c 9.7) patient required surgical revision. "'Major and minor necrosis (4/5), infection (1/5), and seroma (1/5); overall complication includes all patients affected by at least one of the above-mentioned. ${ }^{e}$ Major and minor necrosis (43/51), seroma (8/51), haematoma (5/51), infection (5/51), expander explanation (5/51); overall complication includes all patients affected by at least one of the above-mentioned. d, Both outcomes was statistically significant $(p=0.019)$. fFat necrosis following a complex two-pedicle therapeutic mammaplasty and axillary node clearance, ${ }^{g}$ complications described as "wound breakdown". "Surgical-site infections, wound dehiscence, necrosis, seroma, haematoma, expander exposed, expander removed, return to operation room 
Table 2. The use of NPWT in complicated wounds after implant-based breast reconstruction surgery

\begin{tabular}{|c|c|c|c|c|c|}
\hline Study & $\begin{array}{l}N \text {, breasts, } \\
\text { range of age } \\
\text { (years) }\end{array}$ & Types of lesion & $\begin{array}{l}\text { NPWT duration, } \\
\text { frequency of dressing } \\
\text { change (days) }\end{array}$ & Additional treatment & $\begin{array}{l}\text { NPWT } \\
\text { outcome }\end{array}$ \\
\hline $\begin{array}{l}\text { Accurso } \\
\text { et al. } 2017, \\
\text { case report }\end{array}$ & $1^{a}, 1,54$ & $\begin{array}{l}\text { Seroma/hematoma and } \\
\text { skin necrosis }{ }^{c}\end{array}$ & $21^{d}, 3$ & $\begin{array}{l}\text { Draining and daptomycin } 350 \text { mg daily } \\
\text { IV, implant removal, rinsing of the cavity, } \\
\text { inserting new implant }\end{array}$ & $\begin{array}{l}\text { Healing } \\
\text { achieved }^{f}\end{array}$ \\
\hline $\begin{array}{l}\text { Cheong et al. } \\
\text { 2016, case } \\
\text { series }\end{array}$ & $5,8^{b}, 36-57$ & $\begin{array}{l}\text { Wound dehiscence (4), } \\
\text { abscess (3), skin necrosis (1), } \\
\text { surgical site infection (1) }\end{array}$ & $7^{\mathrm{e}}, 2$ & $\begin{array}{l}\text { Removing of breast implants and } \\
\text { washout, packing operation cavity with } \\
\text { sterile foam }\end{array}$ & $\begin{array}{l}\text { Healing } \\
\text { achieved } \\
\text { (8/8 breasts)g }\end{array}$ \\
\hline
\end{tabular}

insertion. Patients with surgical sites affected by infection, skin necrosis, dehiscence, and seroma/haematoma were taken to the operating room for the removal of implant, rinsing of the cavity, and wound washout. Subsequently, the VAC system was applied and the dressing was changed for 2-3 days. Ten treated breasts (six patients) achieved healing, wherein duration of NPWT ranged from seven to 21 days (Table 2) [20, 21]

\section{The use of NPWT in breast reconstruction using the patients' own tissues}

As well as implant-based surgery there is also a possibility to reconstruct the breast using a latissimus dorsi flap, although it is connected with high rate of complications (back skin necrosis, breast skin necrosis, haematoma), especially donor site seroma, which occurs in approximately $60 \%$ to $80 \%$ of cases $[22,23]$. There is a study suggesting that the use of NPWT leads to a decrease of seroma formation (from $70 \%$ to $15 \%)$, the mean percutaneous aspirated volume (from $193 \mathrm{ml}$ to $26 \mathrm{ml}$ ), and the number of percutaneous aspirations (from three to one). There were no significant differences in the duration of drainage, the total drainage volume, and hospitalisation time. The study has limitations because of the small sample sizes (20 patients in the control group and 20 in the NPWT group), so there is a need for further investigations to confirm the results [24].

\section{Application of NPWT in breast plastic surgery}

Reduction mammoplasty is one of the most common procedures in plastic surgery, and it is beneficial for patients with symptomatic macromastia because of increased self-esteem and back, neck, and shoulder pain relief in about $76 \%$ cases $[25,26]$. Despite its positive effects breast reduction is connected with complications such as seroma, minor dehiscence, infection, and delayed healing [27]. A prospective, within-patient, randomised study was carried out with 200 participants. Women aged over 18 years without any factors affecting healing (no pregnancy or lactation, no use of steroids, no tattoos in the area of the incision, no scar problems or allergies to product components) were included in this study; post-surgical incisions $>30 \mathrm{~cm}$ and active bleeding were exclusion criteria. The NPWT duration time was 14 days, and the system generated $-80 \mathrm{mmHg}$ negative pressure to the wound surface. Treating closed incisional wounds after bilateral reduction mammoplasty with the VAC system resulted in a decrease of overall complications (NPWT $56.8 \%$ vs. standard care $61.8 \% ; p=0.004$ ) and protected from wound dehiscence (NPWT $16.2 \%$ vs. standard care $26.4 \%$; $p<0.001$ ). Application of negative pressure resulted in significant reduction of superficial (from $17.8 \%$ to $11.2 \%$ ) and partial (from $9.6 \%$ to $3.6 \%$ ) dehiscence; there was no significant reduction in deep dehiscence because of the small number of patients with this type of complication. Ninety-day follow-up revealed an advantage of the NPWT - at 7, 21, and 42 days after surgery there were significantly fewer cases of wound dehiscence (16.2\% in the NPWT group and $26.4 \%$ in the standard care group at day $21, p<0.001$ and $19.3 \%$ vs. $29.4 \%$ at day $42, p<0.001$ ). At 90 days there were a comparable number in the standard care and NPWT groups (14). Galiano et al. proved that there is greater benefit from using NPWT in patients with high BMI. What is more, the effects of vacuum-assisted closure increase with the weight of tissue resection [14].

Tanaydin et al. in 2018 conducted a prospective, randomised, controlled study on 32 patients with a mean age of 40.9 years (ranging from 18 to 61 years) treated with bilateral reduction mammoplasty; patients with factors delaying healing and skin conditions such as cutis laxa, hypertrophic scarring or keloids, postsurgical incisions still actively bleeding, and exposure of blood vessels, organs, bone, or tendon at the base of the reference wound were excluded from research [13]. Each patient received NPWT $(-80 \mathrm{mmHg})$ on one breast and fixation strips on the another; follow-up visits were performed at day 0 (baseline, post-surgery), 7, 21, 42, 90, 180, and 365. Wound healing complications were defined as delayed healing (surgical incision not $100 \%$ closed at day 7 post-surgery), or occurrence of dehiscence or infection within 21 days post-surgery. The study showed that the total number of wound complications was significantly lower for the NPWT-treated breasts $(p<0.004)$ and there was significantly less dehiscence for the breasts treated with NPWT compared to the sites treated with fixation strips $(p<0.001)$. Aesthetic appearance and quality of scarring was significantly $(p<0.05)$ better in breasts treated with the NPWT using the VAS (visual analogue scale) and PSOAS (Patient and Observer Scar Assessment Scale) scores; however, skin viscoelasticity, transepidermal water loss, and hydration measurements showed no consistent significant improvement at one year follow-up [10, 13]. 
Ferrando et al. in 2018 compared negative-pressure therapy (17 patients, 25 surgeries) with standard dressing (20 patients, 22 surgeries) in patients undergoing complex oncological breast surgeries and reconstructions. The VAC provided $-125 \mathrm{mmHg}$ pressure for seven days; the standard dressings involved Steri-Strip skin adhesive closure for 14 days (changed after seven days). There was a significant reduction in overall complications between groups: $4 \%(1 / 25)$ in the NPWT group and 45\% (10/22) in the standard wound treatment group ( $p=0.001)$; skin necrosis incidence was significantly lower in the NPWT group than in the standard dressing group ( $4 \%$ vs. $32 \% ; p=0.02$ ). The aesthetic result was also better in the NPWT group: in PSAS (median score 11 vs. 20; $\max .50 ; p=0.002$ ), OSAS (median score 7 vs. 24; $\max .50 ; p=0.01$ ), and MSS (median score 7 vs. $12 ; p=0.001$ ); however, there was no significant reduction in BIS score [28].

\section{Treatment of breast inflammatory diseases using NPWT}

Non-puerperal mastitis encompasses all the causes of inflammatory changes in the female breast and mammilla not related to lactation, for which the aetiology is still unknown. In general, non-puerperal mastitis does not require surgery to be treated, but in the literature there are cases describing patients unsuccessfully healed with non-surgical methods and healing with surgery connected with NPWT [29]. In total, seven cases of application of a VAC system for two weeks resulted in resolution of inflammatory symptoms. Although there were single differences between each treatment, healing was achieved in all cases [30, 31]. We identified two studies according to non-healing wounds, in which damaged tissues regenerated faster after NPWT, but these observations are based on the authors' experience and cannot be taken as objective evidence [16, 32]. The use of NPWT in chronic breast wounds is summarised in Table 3.

\section{Conclusions}

Current data suggest that the use of NPWT in implant-based breast reconstruction surgery decreases overall complications in comparison with standard wound treatment, especially skin flap necrosis. What is more, there is a supposition that as much as $96 \%$ of breast wounds may achieve healing at three months after surgery, but this has to be confirmed in larger prospective studies $[15,17,19]$. It may be useful for the treatment of complicated wounds after implant-based breast reconstruction surgery, but it has been demonstrated only by cases series, so there is a need for stronger evidence [20, 21]. Despite the fact that vacuum-assisted closure does not significantly reduce the duration of drainage, the total drainage volume and hospitalisation time in patients who underwent breast reconstruction using latissimus dorsi flap is beneficial because the use of NPWT leads to a decrease of seroma formation, the mean percutaneous aspirated volume, and the number of percutaneous aspirations [24]. Generating $-80 \mathrm{mmHg}$ negative pressure to the wound surface after bilateral reduction mammoplasty resulted in a decrease of overall complications and significant reduction of superficial and partial dehiscence; visual scale scores showed that quality of scarring was better in breasts treated with NPWT $[10,13,19]$. However, at one-year follow-up there was no improvement in skin viscoelasticity, transepidermal water loss. and hydration measurements [10, 13]. Furthermore, in several cases the application of a VAC system for two weeks due to non-puerperal mastitis allowed resolution of inflammatory symp-

Table 3. Chronic and non-healing breast wounds successfully treated by negative-pressure wound therapy

\begin{tabular}{|c|c|c|c|c|c|}
\hline Study & $\begin{array}{l}N \text {, breasts, } \\
\text { range of age } \\
\text { (years) }\end{array}$ & Types of lesion & $\begin{array}{l}\text { NPWT duration, } \\
\text { frequency of } \\
\text { dressing change } \\
\text { (days) }\end{array}$ & Previous treatment & NPWT outcome \\
\hline $\begin{array}{l}\text { Luedders } \\
\text { et al. } 2011, \\
\text { case series }\end{array}$ & $5,5,42-64$ & $\begin{array}{l}\text { Non-puerperal } \\
\text { mastitis, breast } \\
\text { abscess }^{a}\end{array}$ & $\begin{array}{l}\text { 4-13 days, } \\
\text { 3-4 days }\end{array}$ & $\begin{array}{l}\text { Incision and drainages; secondary } \\
\text { reduction of tissue; hydrocolloid closure } \\
\text { and wound lavage; antibiotic therapy }\end{array}$ & $\begin{array}{l}\text { Healing achieved } \\
\qquad(5 / 5)\end{array}$ \\
\hline $\begin{array}{l}\text { Namdaroglu } \\
\text { et al. } 2016 \text {, } \\
\text { case series }\end{array}$ & $2,2,25-31$ & $\begin{array}{l}\text { Non-puerperal } \\
\text { mastitis, breast } \\
\text { abscess }\end{array}$ & $\begin{array}{l}14 \text { days, } \\
3 \text { days }\end{array}$ & $\begin{array}{l}\text { Incision and drainages, antibiotic therapy }{ }^{f} \text {, } \\
\text { oral prednisolone } 0.5 \mathrm{mg} / \mathrm{kg} / \text { day, surgery } \\
\text { and wide excisions of the diseased ducts }\end{array}$ & $\begin{array}{l}\text { Healing achieved } \\
\qquad(2 / 2)\end{array}$ \\
\hline $\begin{array}{l}\text { Stoeckel } \\
\text { et al. } 2006, \\
\text { case series }\end{array}$ & $\begin{array}{l}\text { 15, no data, } \\
\text { no data }\end{array}$ & $\begin{array}{c}\text { Complex breast } \\
\text { wounds }^{b}\end{array}$ & $\begin{array}{c}\text { 3-54 days } \\
\text { no data }\end{array}$ & No data & $\begin{array}{l}7 / 15 \text { healed by } \\
\text { secondary intention, } \\
6 / 15 \text { treated with } \\
\text { subsequent skin } \\
\text { grafting, } 2 / 15 \text { delayed } \\
\text { primary closure }\end{array}$ \\
\hline $\begin{array}{l}\text { Dian et al. } \\
\text { 2010, case } \\
\text { series }\end{array}$ & $4,4,61-66$ & $\begin{array}{l}\text { Surgical site affected } \\
\text { by radiation therapy } \\
\text { due to breast cancer }\end{array}$ & $\begin{array}{c}\text { Approximately } \\
4 \text { weeks }^{d} \text {, no data }\end{array}$ & No data & $\begin{array}{l}\text { 4/4 wound reduction, } \\
1 / 4 \text { patients died } \\
\text { before wound closure }\end{array}$ \\
\hline
\end{tabular}

NPWT-negative pressure wound therapy. ${ }^{a}$ Four patients had a positive wound culture of Staphylococcus epidermis, one was positive for B-haemolytic streptococci. ${ }^{b}$ Four of the patients had complicated transverse rectus abdominis myocutaneous flap wounds and one had a latissimus dorsi flap wound. ${ }^{c}$ Mean 15 days. ${ }^{d}$ Data shown only in one of cases. 'Used antibiotics: amoxicillin, amoxicillin+clavulanicacid, ciprofloxacin, flucloxacillin, trimethoprim + sulfametoxazole, cefuroxime, clindamycin, ciprofloxacin. f In $^{\prime}$ one patient with positive bacterial growth: amoxicillin + clavulanicacid 
toms [30, 31]. Currently NPWT is successfully used in other surgical branches such as chronic wound, abdominal, cardiothoracic and orthopaedic trauma [33-36]. Further studies, providing evidence of high quality, are needed to make vacuum-assisted closure more common in breast surgery.

\section{The authors declare no conflict of interest.}

\section{References}

1. Bovill E, Banwell PE, Teot L, et al. Topical negative pressure wound therapy: A review of its role \& guidelines for its use in the management of acute wounds. Int Wound J 2008; 5: 511-529.

2. Orgill DP, Bayer LR. Update on negative-pressure wound therapy. Plast Reconstr Surg 2011; 127 (Suppl 1): 105-115.

3. Morykwas MJ, Argenda LC, Shelton-Brown El, et al. Vaccum-Assisted closure: a new method for wound control and treatment: animal studies and basic foundation. Ann Plast Surg 1997; 38: 553-562.

4. Loveluck J, Copeland T, Hill J, Hunt A, Martin R. Biomechanical Modeling of the Forces Applied to Closed Incisions During Single-Use Negative Pressure Wound Therapy. Eplasty 2016; 16: e20.

5. Wilkes RP, Kilpad DV, Zhao Y, Kazala R, McNulty A. Closed incision management with negative pressure wound therapy (CIM): Biomechanics. Surg Innov 2012; 19: 67-75.

6. Semsarzadeh NN, Tadisina KK, Maddox J, Chopra K, Singh DP. Closed incision negative-pressure therapy is associated with decreased surgical-site infections: A meta-analysis. Plast Reconstr Surg 2015; 136: 592-602.

7. Kostaras EK, Tansarli GS, Falagas ME. Use of Negative-Pressure Wound Therapy in Breast Tissues: Evaluation of the Literature. Surg Infect (Larchmt) 2014; 15: 679-685.

8. Ho G, Nguyen TJ, Shahabi A, Hwang BH, Chan LS, Wong AK. A systematic review and meta-analysis of complications associated with acellular dermal matrix-assisted breast reconstruction. Ann Plast Surg 2012; 68: 346-356.

9. Suissa D, Danino A, Nikolis A. Negative-pressure therapy versus standard wound care: A meta-analysis of randomized trials. Plast Reconstr Surg 2011; 128: 498-503.

10. Tanaydin V, Beugels J, Andriessen A, Sawor JH, van der Hulst RRWJ. Correction to: Randomized Controlled Study Comparing Disposable Negative-Pressure Wound Therapy with Standard Care in Bilateral Breast Reduction Mammoplasty Evaluating Surgical Site Complications and Scar Quality. Aesthetic Plast Surg 2018; 42: 1176.

11. Ingargiola MJ, Daniali LN, Lee ES. Does the application of incisional negative pressure therapy to high-risk wounds prevent surgical site complications? A systematic review. Eplasty 2013; 13: e49.

12. Hyldig N, Birke-Sorensen $\mathrm{H}$, Kruse M, et al. Meta-analysis of negative-pressure wound therapy for closed surgical incisions. Br J Surg 2016; 103: 477-486.

13. Tanaydin V, Beugels J, Andriessen A, Sawor JH, van der Hulst RRWJ. Randomized Controlled Study Comparing Disposable Negative-Pres sure Wound Therapy with Standard Care in Bilateral Breast Reduc tion Mammoplasty Evaluating Surgical Site Complications and Scar Quality. Aesthetic Plast Surg 2018; 42: 927-935.

14. Galiano RD, Hudson D, Shin J, et al. Incisional Negative Pressure Wound Therapy for Prevention of Wound Healing Complications Following Reduction Mammaplasty. Plast Reconstr Surg Glob Open 2018; 6: e1560.

15. Kim DY, Park SJ, Bang SI, Mun GH, Pyon JK. Does the Use of Incisiona Negative-Pressure Wound Therapy Prevent Mastectomy Flap Necrosis in Immediate Expander-Based Breast Reconstruction? Plast Reconstr Surg 2016; 138: 558-566.

16. Stoeckel WT, David L, Levine EA, Argenta AE, Perrier ND. Vacuum-assisted closure for the treatment of complex breast wounds. Breast 2006; 15: 610-613.

17. Gabriel A, Sigalove SR, Maxwell GP. Initial Experience Using Closed Incision Negative Pressure Therapy after Immediate Postmastectomy Breast Reconstruction. Plast Reconstr Surg Glob Open 2016; 4: e819.

18. Holt R, Murphy J. PICO ${ }^{\top M}$ incision closure in oncoplastic breast surgery: a case series. Br J Hosp Med 2015; 76: 217-223.
19. Gabriel A, Sigalove S, Sigalove N, et al. The Impact of Closed Incision Negative Pressure Therapy on Postoperative Breast Reconstruction Outcomes. Plast Reconstr Surg Glob Open 2018; 6: e1880.

20. Accurso A, Rocco N, Accardo G, et al. Innovative Management of Implant Exposure in ADM/Implant-Based Breast Reconstruction with Negative Pressure Wound Therapy. Aesthetic Plast Surg 2017; 41: 36-39.

21. Cheong JY, Goltsman D, Warrier S. A New Method of Salvaging Breast Reconstruction After Breast Implant Using Negative Pressure Wound Therapy and Instillation. Aesthetic Plast Surg 2016; 40: 745-748.

22. Daltrey I, Thomson H, Hussien M, Krishna K, Rayter Z, Winters ZE. Randomized clinical trial of the effect of quilting latissimus dorsi flap donor site on seroma formation. Br J Surg 2006; 93: 825-830.

23. Menke H, Erkens M, Olbrisch RR. Evolving concepts in breast reconstruction with latissimus dorsi flaps: Results and follow-up of 121 consecutive patients. Ann Plast Surg 2001; 47: 107-114.

24. Angspatt A, Laopiyasakul T, Pungrasmi P, Suwajo P. The role of negative-pressure wound therapy in latissimus dorsi flap donor site seroma prevention: A cohort study. Arch Plast Surg 2017; 44: 308-312.

25. The American Society for Aesthetic Plastic Surgery. Cosmetic Surgery National Data Bank Statistics 2014. https://www.surgery.org/sites/ default/files/2014-Stats.pdf

26. Thoma A, Sprague S, Veltri K, Duku E, Furlong W. A prospective study of patients undergoing breast reduction surgery: Health-related quality of life and clinical outcomes. Plast Reconstr Surg 2007; 120: 13-26.

27. Gulcelik MA, Dogan L, Camlibel M, et al. Early complications of a reduction mammoplasty technique in the treatment of macromastia with or without breast cancer. Clin Breast Cancer 2011; 11: 395-399.

28. Ferrando PM, Ala A, Bussone R, Bergamasco L, Actis Perinetti F, Malan F. Closed Incision Negative Pressure Therapy in Oncological Breast Surgery. Plast Reconstr Surg Glob Open 2018; 6: e1732.

29. Tan H, Li R, Peng W, Liu H, Gu Y, Shen X. Radiological and clinical features of adult non-puerperal mastitis. Br J Radiol 2013; 86: 20120657.30

30. Luedders DW, Bohlmann MK, Hornemann A, Dittmer C, Diedrich K, Thill M. Successful application of vacuum-assisted closure therapy for treatment of mastitis-associated chronic breast wounds. Arch Gynecol Obstet 2011; 283: 1357-1362.

31. Namdaroglu OB, Yazici H, Ozturk AM, et al. Negative-pressure Wound Therapy in Chronic Inflammatory Breast Diseases. J Breast Heal 2016; 12: $91-93$.

32. Dian D, Bodungen V, Himsl I, et al. Worldwide Wrst experiences with vacuum-assisted closure as alternative treatment method to repair defects of an extended thoracic wall recurrence of breast cancer. Arch Gynecol Obstet 2010; 281: 927-932.

33. Vig S, Dowsett C, Berg L, et al. Evidence-based recommendations for the use of negative pressure wound therapy in chronic wounds: Steps towards an international consensus. J Tissue Viability 2011; 20 (Suppl 1): S1-18.

34. Pellino G, Sciaudone G, Selvaggi F, Canonico S. Prophylactic negative pressure wound therapy in colorectal surgery. Effects on surgical site events: current status and call to action. Updates Surg 2015; 67: 235 245.

35. Segers P. Use of Incisional Negative Pressure Wound Therapy on Closed Median Sternal Incisions after Cardiothoracic Surgery: Clinical Evidence and Consensus Recommendations. Med Sci Monit 2014; 20: 1814-1825.

36. Stannard JP, Volgas DA, McGwin G, et al. Incisional negative pressure wound therapy after high-risk lower extremity fractures. J Orthop Trauma 2012; 26: 37-42.

\section{Address for correspondence}

\section{Damian Matusiak}

Chair of Surgery and Oncology

Clinic of General Surgery and Surgical Oncology

Faculty of Medicine and Health Sciences

University of Zielona Gora

28 Zyty St.

65-046 Zielona Góra, Poland

e-mail: damian.matusiak1992@gmail.com

Submitted: 4.02.2019

Accepted: 2.04 .2019 